\title{
AN EMPIRICAL RESEARCH ON ECO-COMPENSATION STRATEGY FOR HANDLING NON-POINT SOURCE POLLUTION OF WATER BODIES
}

\author{
LIN, J. \\ School of Economics and Management, Zhejiang University of Water Resources and Electric \\ Power, Hangzhou, China \\ (e-mail: linjielinjie1@163.com; phone: +86-0571-86929075)
}

(Received $5^{\text {th }}$ Feb 2019; accepted $6^{\text {th }}$ Mar 2019)

\begin{abstract}
This paper attempts to disclose the farmers' selection bases among different eco-compensation options for the reduction of fertilizer use, a typical non-point source (NPS) of water pollution. Firstly, the reduction methods were divided into six types. Then a survey was carried out on the farmers near two water bodies in south-eastern China's Zhejiang Province, namely, Qiaodun Reservoir and Siming Lake Reservoir. It was found that when multiple options are available, financial compensation is the most favoured one among farmers, followed by technical learning and policy compensation; the organic fertilizer has the lowest acceptance. Next, a simultaneous bivariate probit model was established to illustrate the effect of each factor on farmers' selection between intellectual and non-intellectual technical compensations, and between alternative and organic fertilizers. Meanwhile, the farmers' intentions on policy compensation were examined by the binary probit model. The modelling results show that: the farmers prefer compensation options that complement each other and wish the government could offer integrated compensation plans of these options; the age and education level of house owner, coupled with family income, farmland area, farmland fragmentation, production efficiency and farmers' willingness to reduce fertilizer application all have important impacts on the selection of compensation means.
\end{abstract}

Keywords: chemical fertilizer, non-point source (NPS) pollution, direct eco-compensation, reservoir, farmers' participation

\section{Introduction}

Humans freely receive ecological services from properly-functioning ecosystems like the aquatic ecosystem, i.e. the ecosystem in a body of water (Karabulut et al., 2016). Water bodies are the sources of water supply to urban and rural areas, and require strict measures on environmental safety (Ademila and Saloko, 2018; Joldeș et a., 2017; Jian, 2018; Li et al., 2015; Ganiron, 2017; Grafton et al., 2017; Tian et al., 2018). However, fresh water resources have been utilized in a non-sustainable way, as they are widely viewed as inexhaustible, free or low-cost public resources (Perry and Berry, 2016; Yihdego and Khalil, 2017). To solve the problem, China has restricted and even banned the development of many water bodies, and invested more into the construction of sewage pipes and other discharge facilities. These moves have paid off: industrial point source (PS) pollution is placed under control, and domestic wastewater can now be disposed of satisfactorily (Moges et al., 2016; Fales et al., 2016).

Despite the above efforts, the agricultural non-point source (NPS) pollution in crop farming still poses a challenge to the safety of water bodies, because the NPS pollution is highly dispersed, concealed, random, uncertain, extensive and undetectable (Álvarez et al., 2017; Smith et al., 2017; Herrera et al., 2017). This universal problem, especially the fertilizer NPS pollution, has attracted much attention from scholars around the world (Jin, 2013; Pott and Fohrer, 2017). Studies have 
shown that dissolved fertilizer, a main pollutant to water quality, can enter water bodies through surface runoff, farmland irrigation and drainage (Kreuger et al., 2008; Kronvang et al., 2008; Neumann et al., 2011; Sun et al., 2012).

On the correlation between agriculture and water quality, irresponsible use of farmland has been widely regarded as the primary cause of agricultural NPS pollution to water bodies (Rodrigues et al., 2018; Corneil et al., 2018; Li et al., 2015). Since the "household responsibility system" was implemented in late 1970s, Chinese farmers have been officially recognized as the basic units of agricultural production, management and decision-making (Ji et al., 1999). The agricultural NPS pollution can be attributed to the irrational decisions of farmers under various factors, ranging from social environment, item property, individual preference to laws and regulations (Feng et al., 2006; Liang et al., 2015). The farmers tend to make irrational decisions when they are worried about the yield and production scale, unclear of the pollution source or the importance of pollution control, and in lack of practice instructions or convenient farming techniques (Zhang, 2015).

One of the viable options to reduce agricultural NPS pollution to water bodies lies in conservation tillage (Doreen et al., 2018). This is a tillage system that creates a suitable soil environment for growing a crop and that conserves soil, water and energy resources mainly through the reduction in the intensity of tillage, and retention of plant residues. However, the conservation tillage may bring the risk of output reduction, and make farming income uncertain. As a result, many farmers are reluctant to implement conservation tillage without proper compensation, even if they are risk takers (Klemme, 1985).

In the last two decades, many international organizations and governments have provided eco-compensations for protective actions aiding water bodies (Wunder, 2015; Ze et al., 2017). A perfect eco-compensation mechanism helps to enhance the values and benefits of ecological services, remove policy constraints on farmers' demand for individual development, and arouse the enthusiasm of farmers in pollution control activities (Xie and Li, 2016; Vogl et al., 2017; Villarroya et al., 2014; Chang et al., 2013). Out of the many eco-compensation policies, financial compensation like transfer payment has long been the most effective way to prevent agricultural NPS pollution to regional water bodies, because it is easy to quantify and measure. As farmers now expect more diverse means of compensation, it is imperative to develop various compensation mechanisms according to local conditions (Research Group on Eco-Compensation Mechanism and Policies in China, 2007).

The farmers must make prudent choices among various compensation mechanisms. After all, not every form of compensation is effective, and some may even have negative consequences. For example, over compensation may dampen the farmers' enthusiasm about sustainable farming and environmental protection, in that the subsidy to be received is negatively correlated with the environmental improvement (Aretino et al., 2001). Moreover, subsidy may distort the resource allocation, giving subsidized farmers more market power over the unsubsidized (Macintosh and Denniss, 2004). Rationality and fairness are two key attributes of a good compensation mechanism. If either of them is overlooked, the compensation will not achieve the desired goals.

Currently, the government, the dominating party of eco-compensation practices, fails to understand the wishes of farmers or their reasons to change behavior (Huber et al., 2012). With the changes in farmers' demand, the compensation effectiveness now 
hinges on the rationality of the compensation means, in addition to the amount of compensation. However, there is no consensus on what makes a compensation policy rational. Some scholars held that farmers are biased towards cash compensation (Xu et al., 2013; Yang and Cai, 2012), while some others believed that farmers prefer technical compensation (Shi et al., 2014). To sum up, these discussions show that the limitations should be considered in the design of any compensation method, because the farmers' preference for compensation means varies with regions, cultures and populations. This means the choice of compensation tools should be discussed from a more microscopic perspective. Therefore, this paper explores farmers' choice between different compensation means for the abandonment of chemical fertilizer, a typical NPS of agricultural pollution to water bodies.

\section{Selection bases of compensation means}

\section{Classification of compensation means}

The compensation methods for prevention and control of agricultural NPS pollution mainly fall into four categories, namely, financial compensation, physical compensation, technical compensation and policy compensation. The details on these types of compensation are provided below.

\section{(1) Financial compensation}

As its name implies, financial compensation refers to the direct financial incentives for farmers to adopt protective measures, or the financial subsidy for the cost of taking such measures. It is commonly applied in China's "Grain for Green" program.

\section{(2) Physical compensation}

Physical compensation, e.g. seed compensation and gasoline compensation, is a collective term for any compensation means that improves the productive capacity of ecological service providers through the provision of production factors or living factors.

\section{(3) Technical compensation}

Technical compensation is either intellectual or non-intellectual. The intellectual technical compensation aims to enhance the implicit, materialized technologies, such as the farmers' ability of unified farmland management, through training, demonstration and subsidies. By contrast, the non-intellectual technical compensation mainly subsidizes farmers for the implementation of knowledge-based technologies.

\section{(4) Policy compensation}

Policy compensation generally means the preferential policies issued by the superior government to the lower government, giving the recipients various preferential treatments on agricultural structure, employment and social security.

Each of the above compensation methods has its advantages and disadvantages. In fact, the selection of compensation means is tradeoff between financial and nonfinancial compensations, between transfusion and hematopoietic compensations, as well as between coupling and decoupling compensations. 


\section{Typical selection bases}

For the farmers who have adopted conservation tillage, eco-compensation may exist in direct forms as funds, physical objects, technologies or policies, and in indirect forms as government-funded projects on environmental protection, economic construction and social security. The direct compensation boosts the income and productivity of the farmers, while the indirect compensation benefits the farmers through the improvement of the social environment.

In this paper, the direct compensation is taken as the example to illustrate the bases of farmers' selection among different compensation means. This is because direct compensation reminds farmers of the purpose of compensation, while giving them direct benefits. Moreover, direct compensation can be investigated by closed and open questionnaire surveys, which are familiar to farmers.

Considering the important supplementary function of policy compensation, this paper makes "other jobs" an indicator of policy compensation related to agricultural activities. Here, "other jobs" refers to the jobs created by agricultural restructuring and offered by other industries, with the aim to encourage farmers to stop un-green farming practices, such as planting polluting crops.

In view of the general fertilization techniques of farmland, our questionnaire offers the farmers different combinations of compensation options targeting six conventional control methods for NPS pollution of chemical fertilizer. These control methods directly affect the farmland management (Table 1):

1. Financial compensation;

2. Physical compensation: Grain compensation;

3. Technical compensation: Training on "formula fertilization by soil testing" (FFST) (technical learning); provision of FFST fertilizer (alternative fertilizer); subsidies for commercial organic or green manure (organic fertilizer);

4. Policy compensation: Provisions of other job opportunities (other jobs).

The above compensation means all belong to direct compensation. The financial compensation and physical compensation are transfusion compensation, while technical compensation and policy compensation are hematopoietic compensation. Moreover, financial, physical and technical compensations fall in the category of coupling compensation, while policy compensation fits into decoupling compensation.

Table 1. Eco-compensation means and NPS pollution control methods

\begin{tabular}{|c|c|c|c|c|c|c|}
\hline $\begin{array}{l}\text { Option } \\
\text { content }\end{array}$ & $\begin{array}{c}\text { Financial } \\
\text { compensation }\end{array}$ & $\begin{array}{c}\text { Grain } \\
\text { compensation }\end{array}$ & $\begin{array}{c}\text { Technology } \\
\text { learning }\end{array}$ & $\begin{array}{c}\text { Alternative } \\
\text { fertilizer }\end{array}$ & $\begin{array}{l}\text { Organic } \\
\text { manure }\end{array}$ & Other jobs \\
\hline \multirow{4}{*}{$\begin{array}{l}\text { Division } \\
\text { method }\end{array}$} & $\begin{array}{c}\text { Financial } \\
\text { compensation }\end{array}$ & $\begin{array}{c}\text { Physical } \\
\text { compensation }\end{array}$ & \multicolumn{3}{|c|}{ Technical compensation } & $\begin{array}{c}\text { Policy } \\
\text { compensation }\end{array}$ \\
\hline & $\begin{array}{c}\text { Financial } \\
\text { compensation }\end{array}$ & \multicolumn{5}{|c|}{ Non-financial compensation } \\
\hline & \multicolumn{2}{|c|}{ Transfusion compensation } & \multicolumn{4}{|c|}{ Hematopoietic compensation } \\
\hline & \multicolumn{5}{|c|}{ Coupling compensation } & $\begin{array}{c}\text { Decoupling } \\
\text { compensation }\end{array}$ \\
\hline
\end{tabular}




\section{Materials and methods}

\section{Study area overview}

Our research targets Qiaodun Reservoir in Yuyao City and Siming Lake Reservoir in Cangnan County, southeastern China's Zhejiang Province. The two medium-sized reservoirs are the major sources of water supply to the county. However, both water bodies have suffered from severe eutrophication, and face potential agricultural pollution.

Thanks to the provincial eco-compensation practices, the local farmers are now aware of conservation tillage, laying a good basis for our survey. However, the farmers mainly rely on agriculture for a living and have not acquired sufficient knowledge on scientific farming. Since rice is the dominant crop in the study area, rice growers were selected as the research objects.

\section{Survey design description}

From March 2014 to January 2015, our survey was carried out in 12 villages near Qiaodun Reservoir and 9 villages near Siming Lake Reservoir. These villages were identified by stratified random sampling, considering such factors as rice planting area, economic development and location. In each village, 30 farmers were selected for the one-on-one interview, which was designed to acquire their basic information and selection bases for compensation means.

A questionnaire was prepared for the interview. Since real-world eco-compensations often combine multiple methods, our questionnaire offers the farmers with six compensation options targeting conventional control methods for NPS pollution of chemical fertilizer, and asks them to choose three compensation methods out of the six options.

Based on the questionnaire, the interview was conducted in three steps: (1) Present the compensation options, ask the farmer to select the most desired option, and mark the selected option with the number "1"; (2) Ask the farmer to select the next desired option from the unselected options, and mark the selected option with the number "2"; (3) Ask the farmer to select the next desired option from the unselected options, and mark the selected option with the number " 3 ".

The option selected in Step 1 is the compensation means with the maximum utility. The farmers have basically the same demand for compensation means, except a slight difference between individuals. The general principle is that the attributes and features of the selected option must satisfy the farmers' requirements of use. In other words, the compensation options are selected based on the farmers' demand and preference on the attributes of such options.

A total of 360 questionnaires were sent out to the villages near Qiaodun Reservoir and 270 to those near Siming Lake Reservoir. In the end, 323 and 218 valid questionnaires were returned from the two groups of villages, respectively.

\section{Sample features}

Table 2 sums up the features of the interviewees. It can be seen that $90 \%$ of the interviewees are males, which reflects the high labor intensity of rice production. Besides, the preference for food crop planting increases with the age of farmers, as over $80 \%$ of food crop growers are over 50 . 
Table 2. Sample features

\begin{tabular}{c|c|c|c|c}
\hline Variable & Option & Total & Qiaodun & Siming Lake \\
\hline \multirow{2}{*}{ Gender } & Female & 21 & 8 & 13 \\
& Male & 520 & 315 & 205 \\
\hline \multirow{3}{*}{ Family population } & $<3$ & 138 & 68 & 70 \\
& $3 \sim 5$ & 245 & 131 & 114 \\
& $>5$ & 158 & 124 & 34 \\
\hline \multirow{5}{*}{ Income } & $<10,000$ & 13 & 13 & 0 \\
(unit: RMB) & $10,000 \sim 20,000$ & 39 & 31 & 8 \\
& $20,000 \sim 30,000$ & 31 & 13 & 18 \\
& $30,000 \sim 50,000$ & 137 & 92 & 45 \\
& $50,000 \sim 70,000$ & 114 & 90 & 24 \\
& $>70,000$ & 178 & 84 & 94 \\
\hline \multirow{5}{*}{ Education level } & Illiteracy & 264 & 201 & 63 \\
& Primary school has not graduated & 29 & 12 & 17 \\
& Primary school graduation & 146 & 79 & 67 \\
& Junior high school & 71 & 29 & 42 \\
& Senior high school & 28 & 2 & 28 \\
& College or above & 3 & 0 & 3 \\
\hline Age & $>40$ & 25 & 10 & 15 \\
& $40 \sim 50$ & 76 & 25 & 51 \\
& $50 \sim 60$ & 149 & 86 & 63 \\
& $60 \sim 70$ & 210 & 137 & 73 \\
& $>70$ & 81 & 65 & 16 \\
\hline & & & &
\end{tabular}

\section{Methods and modelling}

The farmers' willingness to select a compensation means is a binary discrete choice variable. Both financial and physical compensations belong to transfusion compensation, and directly make up for the economic losses of farmers. There might be some correlations between the two compensation options, because they tend to be selected by farmers under the same influencing factors. The same relationship may exist between intellectual and non-intellectual technical compensations.

Since financial and grain compensations are independent of each other, there are four possible choices for farmers: selecting both options, selecting financial compensation, selecting grain compensation and selecting neither option.

Let $Y_{1}$ and $Y_{2}$ be the selection of financial compensation and that of grain compensation, respectively. If the farmer being interviewed selects financial compensation, the value of $Y_{1}$ should be recorded as 1 ; otherwise, the value of $Y_{1}$ should be recorded as 0. Similarly, if the farmer selects grain compensation, the value of $Y_{2}$ should be recorded as 1 ; otherwise, the value of $Y_{2}$ should be recorded as 0 . Then, the four possible choices can be expressed as $(1,1),(1,0),(0,1)$ and $(0,0)$, respectively.

In light of the above, a simultaneous bivariate probit model was established to illustrate the effect of each factor on farmers' selection (Greene, 2008). Extended from the probit model, the established model is suitable for simultaneous equations satisfying the following two conditions: the random perturbations of the equations are inter- 
correlated, such that the equations can be estimated at the same time; the model has two output variables. The mathematical expression of the model is shown in Equation 1.

$$
\left\{\begin{array}{l}
Y_{1}^{*}=\beta_{1}+\beta_{1}^{\prime} X_{1}+\varepsilon_{1} \\
Y_{2}^{*}=\beta_{2}+\beta_{2}^{\prime} X_{2}+\varepsilon_{2} \\
E\left(\varepsilon_{1}\right)=E\left(\varepsilon_{2}\right)=0 \\
\operatorname{var}\left(\varepsilon_{1}\right)=\operatorname{var}\left(\varepsilon_{2}\right)=1 \\
\operatorname{cov}\left(\varepsilon_{1}, \quad \varepsilon_{2}\right)=\rho
\end{array}\right.
$$

where $Y_{1}^{*}$ and $Y_{2}^{*}$ are unobservable potential variables depicts the farmer' evaluation of financial and grain compensation, respectively; $X_{1}$ and $X_{2}$ are influencing factors of the farmer' selection; $\beta_{1}, \beta_{1}^{\prime}, \beta_{2}$ and $\beta_{2}^{\prime}$ are estimation parameters; $\varepsilon_{1}$ and $\varepsilon_{2}$ are random perturbation terms that obey bivariate normal distribution, $\rho$ is the correlation coefficient of $\varepsilon_{1}$ and $\varepsilon_{2}$.

If $Y_{1}^{*}>0$, the financial compensation has a positive utility and is favored by the farmer. In this case, the output variable $Y_{1}$ equals 1 . Otherwise, $Y_{1}=0$. If $Y_{2}^{*}>0$, the grain compensation has a positive utility and is favored by the farmer. In this case, $Y_{2}=1$. Otherwise, $Y_{2}=0$.

Under the condition of a significant $\rho$ value, $\varepsilon_{1}$ and $\varepsilon_{2}$ are irrelevant if $\rho=0$, that is, the two equations of our model can be estimated separately, and the estimated results agree with the results of simultaneous estimation; if $\rho>0, Y_{1}$ and $Y_{2}$ complement each other; if $\rho<0, Y_{1}$ and $Y_{2}$ exclude each other.

The simultaneous bivariate probit model was also adopted to analyze the farmers' selection between intellectual and non-intellectual technical compensations, and between alternative and organic fertilizers; the farmers' intentions on policy compensation were examined by the binary probit model.

\section{Variable selection}

As shown in Table 3, the influencing factors in this research include personal information, farmer productivity, family information, farmland features, farmland management, village economy and regional variable. Specifically, personal information covers the age (age) and education level (edu) of house owner; family information refers to the annual family income (inc); farmland features include farmland area (ara) and farmland fragmentation (ldf); farmland management features refers to production efficiency (eff) and farmers' willingness to reduce fertilizer application (wtr); Regional variable (reg) refers to the investigation site the farmer belonged to, Qiaodun reservoir watershed or Siming Lake reservoir watershed.

\section{Results}

With the aid of Stata 9.0 software, the simultaneous bivariate probit model and the binary probit model were adopted for the empirical analysis on farmer's selection of eco-compensation options for chemical fertilizer reduction. The estimation results and significance test results are listed in Table 4.

As shown in Table 4, all four models have high goodness of fit, and some coefficients of the influencing factors passed the significance test and fulfilled the 
expectations. The correlation coefficient of model 1-1 was significant on the $1 \%$ level, revealing the correlation between the selection of financial compensation and that of grain compensation. Meanwhile, the positive value of the correlation coefficient $(P=0.4668)$ shows the complementary effect between the two compensation options: a farmer is more likely to choose grain compensation, if he/she has chosen financial compensation. Similarly, the estimation results of model 1-2 demonstrate that intellectual and non-intellectual technical compensations complement each other, i.e. a farmer tends to select both options at the same time. However, the correlation coefficient of model 1-3 failed the significance test, indicating that farmers' selection of alternative fertilizer is independent from that of organic fertilizer. The binary probit model estimation results of Model 1-4 demonstrate that farmers' choice of other jobs are easily influenced by age of house owner, education level, farmland fragmentation, farmers' willingness to reduce fertilizer application, and regional variable. The impacts of different influencing factors are detailed below.

\section{(1) Age of house owner}

The age of house owner has a positive impact on farmers' selection of financial compensation $(\mathrm{p}<1 \%)$. Then, it can be deduced that old farmers are willing to accept grain compensation, considering the complementary effect between financial and grain compensations. This deduction is proved by the results in the above table: the age of house owner has a positive impact on farmers' selection of grain compensation. These relationships can be explained as follows. Compared with young farmers, old farmers are concerned with collective interests and government instructions, and thus expect a limited compensation for chemical fertilizer reduction. Therefore, financial compensation, known for its simplicity, directness and flexibility, wins more recognition among old farmers than young farmers.

Table 3. Influencing factors

\begin{tabular}{|c|c|c|c|c|}
\hline Type & Variable & Variable definition & $\begin{array}{l}\text { Average } \\
\text { value }\end{array}$ & $\begin{array}{l}\text { Standard } \\
\text { deviation }\end{array}$ \\
\hline \multirow{2}{*}{$\begin{array}{l}\text { Personal } \\
\text { information }\end{array}$} & Age of house owner & $\begin{array}{c}\text { Actual years reported by farmers } \\
\text { (years) }\end{array}$ & 1.9630 & 0.5794 \\
\hline & $\begin{array}{c}\text { Education level of house } \\
\text { owner }\end{array}$ & $\begin{array}{c}1=\text { illiteracy; } 2=\text { elementary } \\
\text { school graduation and below; } \\
3 \text { = elementary school and above }\end{array}$ & 1.8226 & 0.7441 \\
\hline $\begin{array}{l}\text { Family } \\
\text { information }\end{array}$ & Annual family income & $\begin{array}{c}\text { Farmers reported annual household } \\
\text { income (RMB) }\end{array}$ & 5.5174 & 0.1420 \\
\hline \multirow{2}{*}{$\begin{array}{l}\text { Farmland } \\
\text { management } \\
\text { features }\end{array}$} & & $\begin{array}{l}\text { Real value calculated according to } \\
\text { input-output data }\end{array}$ & 0.6143 & 0.0074 \\
\hline & $\begin{array}{l}\text { Farmers' willingness to } \\
\text { reduce fertilizer } \\
\text { application }\end{array}$ & $\begin{array}{c}\text { Farmers' willingness to report } \\
\text { reductions }(\%)\end{array}$ & 0.2886 & 0.0110 \\
\hline \multirow{2}{*}{ Farmland features } & Farmland area & $\begin{array}{l}\text { Farmers reported farmland area } \\
\qquad(\mathrm{Mu})\end{array}$ & 2.3950 & 1.6339 \\
\hline & Farmland fragmentation & $\begin{array}{c}\text { Number of cultivated lands } \\
\text { separated from each other (block) }\end{array}$ & 2.3272 & 0.8290 \\
\hline Regional variable & Investigation site & $\begin{array}{c}1=\text { Qiaodun reservoir watershed; } \\
0=\text { Siming Lake reservoir } \\
\text { watershed }\end{array}$ & 0.5970 & 0.4910 \\
\hline
\end{tabular}


Table 4. The estimation results and significance test results

\begin{tabular}{|c|c|c|c|c|c|c|c|}
\hline \multirow{4}{*}{ Variable } & \multicolumn{6}{|c|}{ Simultaneous bivariate Probit model } & \multirow{2}{*}{\begin{tabular}{|c|} 
Probit model \\
Model 1-4
\end{tabular}} \\
\hline & \multirow{2}{*}{\multicolumn{2}{|c|}{$\begin{array}{c}\text { Model 1-1 } \\
\text { Financial compensation }\end{array}$}} & \multicolumn{2}{|c|}{ Model 1-2 } & \multicolumn{2}{|c|}{ Model 1-3 } & \\
\hline & & & & Technical comp & ensation & & \multirow[b]{2}{*}{ Other jobs } \\
\hline & $\begin{array}{c}\text { Financial } \\
\text { compensation }\end{array}$ & $\begin{array}{c}\text { Grain } \\
\text { compensation }\end{array}$ & $\begin{array}{l}\text { Intelligence } \\
\text { compensation }\end{array}$ & $\begin{array}{c}\text { Non- } \\
\text { intelligence } \\
\text { compensation }\end{array}$ & $\begin{array}{c}\text { Alternative } \\
\text { fertilizer }\end{array}$ & $\begin{array}{l}\text { Organic } \\
\text { manure }\end{array}$ & \\
\hline age & $\begin{array}{l}0.4488^{* * *} \\
(3.0255) \\
\end{array}$ & $\begin{array}{l}0.4749^{* * *} \\
(4.2698) \\
\end{array}$ & $\begin{array}{l}-0.1893^{*} \\
(-1.6679) \\
\end{array}$ & $\begin{array}{l}0.3772^{* * *} \\
(3.1433) \\
\end{array}$ & $\begin{array}{l}-0.2055^{* *} \\
(-1.9669) \\
\end{array}$ & $\begin{array}{l}0.3831^{* * *} \\
(3.3316) \\
\end{array}$ & $\begin{array}{l}-0.8816^{* * * *} \\
(-7.2297)\end{array}$ \\
\hline edu & $\begin{array}{c}0.0151 \\
(0.1385)\end{array}$ & $\begin{array}{l}-0.2176^{* *} \\
(-2.5559)\end{array}$ & $\begin{array}{c}0.0925 \\
(1.0485)\end{array}$ & $\begin{array}{c}-0.0448 \\
(-0.4739)\end{array}$ & $\begin{array}{c}0.0271 \\
(0.3274)\end{array}$ & $\begin{array}{c}0.0766 \\
(0.8508)\end{array}$ & $\begin{array}{l}0.1668^{*} \\
(1.9021)\end{array}$ \\
\hline inc & $\begin{array}{l}-0.1701^{*} \\
(-1.7929)\end{array}$ & $\begin{array}{c}0.0210 \\
(0.3164)\end{array}$ & $\begin{array}{c}0.0717 \\
(1.0293)\end{array}$ & $\begin{array}{c}-0.0624 \\
(-0.8398)\end{array}$ & $\begin{array}{c}0.1022 \\
(1.5850)\end{array}$ & $\begin{array}{c}-0.0183 \\
(-0.2639)\end{array}$ & $\begin{array}{c}0.0528 \\
(0.7719)\end{array}$ \\
\hline ara & $\begin{array}{l}-0.0831^{* *} \\
(-1.9845)\end{array}$ & $\begin{array}{l}-0.0113 \\
(-0.3064)\end{array}$ & $\begin{array}{c}0.0421 \\
(1.1373)\end{array}$ & $\begin{array}{l}0.1093^{*} \\
(1.9570)\end{array}$ & $\begin{array}{l}-0.0025 \\
(-0.0675)\end{array}$ & $\begin{array}{l}0.0867^{*} \\
(1.8170)\end{array}$ & $\begin{array}{c}-0.0243 \\
(-0.6266)\end{array}$ \\
\hline ldf & $\begin{array}{c}-0.0162 \\
(-0.1529) \\
\end{array}$ & $\begin{array}{c}-0.0251 \\
(-0.3135) \\
\end{array}$ & $\begin{array}{c}0.0831 \\
(0.9696) \\
\end{array}$ & $\begin{array}{c}0.1185 \\
(1.3445) \\
\end{array}$ & $\begin{array}{c}0.0440 \\
(0.5632) \\
\end{array}$ & $\begin{array}{c}0.1191 \\
(1.4127) \\
\end{array}$ & $\begin{array}{l}-0.1676^{* *} \\
(-2.0207) \\
\end{array}$ \\
\hline eff & $\begin{array}{l}0.2819^{*} \\
(1.7792) \\
\end{array}$ & $\begin{array}{c}0.1499 \\
(1.1473) \\
\end{array}$ & $\begin{array}{l}-0.2998^{* *} \\
(-2.2499) \\
\end{array}$ & $\begin{array}{c}-0.1372 \\
(-0.9216) \\
\end{array}$ & $\begin{array}{l}-0.2913^{* *} \\
(-2.2862) \\
\end{array}$ & $\begin{array}{c}0.1789 \\
(1.2315) \\
\end{array}$ & $\begin{array}{c}0.1095 \\
(0.8088) \\
\end{array}$ \\
\hline wtr & $\begin{array}{c}0.1906 \\
(0.6211) \\
\end{array}$ & $\begin{array}{c}0.7996^{* * *} \\
(3.3399) \\
\end{array}$ & $\begin{array}{l}-0.7809^{* * * *} \\
(-2.8854) \\
\end{array}$ & $\begin{array}{c}-0.2463 \\
(-0.9707) \\
\end{array}$ & $\begin{array}{l}-0.6674^{* * *} \\
(-2.8124) \\
\end{array}$ & \begin{tabular}{|c|}
-0.3125 \\
$(-1.2817)$ \\
\end{tabular} & $\begin{array}{l}0.4372^{*} \\
(1.8231) \\
\end{array}$ \\
\hline reg & $\begin{array}{l}0.5008^{* *} \\
(2.2180) \\
\end{array}$ & $\begin{array}{l}0.4745^{* * *} \\
(2.7598)\end{array}$ & $\begin{array}{l}-0.5050^{* * * *} \\
(-2.7256)\end{array}$ & $\begin{array}{l}-0.7776^{* * *} \\
(-4.0248)\end{array}$ & $\begin{array}{c}0.2300 \\
(1.3553) \\
\end{array}$ & \begin{tabular}{|l|}
$-1.2717^{* * * *}$ \\
$(-6.6279)$ \\
\end{tabular} & $\begin{array}{c}1.0471^{* * *} \\
(5.6409)\end{array}$ \\
\hline Constant & $\begin{array}{c}0.8519 \\
(1.5329) \\
\end{array}$ & $\begin{array}{l}-0.8377^{* *} \\
(-2.0067) \\
\end{array}$ & $\begin{array}{c}-0.4420 \\
(-1.0160) \\
\end{array}$ & $\begin{array}{c}0.3865 \\
(0.8477)\end{array}$ & $\begin{array}{c}-0.2493 \\
(-0.6208) \\
\end{array}$ & $\begin{array}{c}0.0917 \\
(0.2113) \\
\end{array}$ & $\begin{array}{c}0.6685 \\
(1.5673) \\
\end{array}$ \\
\hline $\begin{array}{c}\text { Log } \\
\text { likelyhood }\end{array}$ & \multicolumn{2}{|c|}{-506.8631} & \multicolumn{2}{|c|}{-562.0101} & \multicolumn{2}{|c|}{-655.8215} & -315.3154 \\
\hline$p$ & \multicolumn{2}{|c|}{$0.4668^{* * * *}$} & \multicolumn{2}{|c|}{$0.1895^{* *}$} & \multicolumn{2}{|c|}{-0.0115} & \\
\hline Pseudo $^{R^{2}}$ & & & & & & & $0.1285^{* * *}$ \\
\hline
\end{tabular}

$*$, ** and $* * *$ mean $\mathrm{p}<10 \%, \mathrm{p}<5 \%$ and $\mathrm{p}<1 \%$, respectively

The age of house owner has a negative impact on farmers' selection of intellectual compensation $(\mathrm{p}<10 \%)$. This is because old farmers are confident about their farming experience, and find re-education unnecessary. In addition, non-intellectual compensation is positively affected by the age of house owner, due to the positive impact of the age on organic fertilizer. In fact, the age is negatively correlated with alternative fertilizer. After all, old farmers are very aware of long-term ecological benefits, as organic fertilizer is the most effective way to reduce chemical fertilizer in individual farmland management.

Furthermore, the age of house owner has a negative impact on policy compensation (other jobs) $(\mathrm{p}<1 \%)$, i.e. old farmers do not like job opportunities other than farming. There are two possible reasons: old farmers want to maintain a stable income and consumption structure, rather than take the risk of reemployment or job-hopping; most employers only recruit people under 60 . 


\section{(2) Education level}

The education level only directly affects the selection of grain compensation and policy compensation (other jobs): it is negatively correlated with the selection of grain compensation $(\mathrm{p}<5 \%)$, and positively with that of policy compensation $(\mathrm{p}<1 \%)$. A possible reason lies in the strong learning and cognitive abilities of well-educated farmers. These farmers are good at acquiring information, clear about government intentions and concerned with rights. In their eyes, compensation is often insufficient and poor in quality. Thus, many of the well-educated farmers want to have other job opportunities. It is worth mentioning that $83 \%$ of well-educated respondents are younger than 50, which confirms the negative correlation between age and policy compensation.

\section{(3) Annual family income}

The annual family income mainly has a negative impact on farmers' selection of financial compensation $(\mathrm{p}<10 \%)$. Rich families are not very dependent on farm income. Their engagement in agricultural activities is mainly a pursuit for high-quality food. Farmers from these families are discouraged by the labor-intensity and strict requirements of conservation tillage. Therefore, financial compensation is not favored by rich families. On the contrary, farmers from poor families prefer financial compensation, and often ask for excessively high compensation due to the poor awareness of scientific farming and conservation policies. Apart from this, the annual family income has a very limited impact on the selection of other compensation options.

\section{(4) Farmland area}

The farmland area has a negative impact on farmers' selection of financial compensation $(\mathrm{p}<5 \%)$. The farmers with lots of farmland prefer non-financial compensation, because of the positive correlation between farmland area and the risk of yield loss under self-management. This is partly verified by farmers' selection of nonintellectual compensation. As shown in Table 4, the selection of non-intellectual compensation is positively affected by the farmland area $(\mathrm{p}<10 \%)$, so does organic fertilizer $(\mathrm{p}<10 \%)$. In addition, it can be seen from farmers' selection of organic fertilizer in different farmland areas that: farmers managing a larger farmland are more willing to make long-term investment. The reason is very simple: such farmers hold a favorable opinion of farming and want to enhance crop yield with organic fertilizer.

\section{(5) Farmland fragmentation}

Farmland fragmentation has a negative impact on farmers' selection of policy compensation $(\mathrm{p}<5 \%)$, which goes against the conventional knowledge that farmers are eager to change jobs when their farmland is fragmented, as fragmentation pushes up transport cost and hinders mechanized farming. Here, farmland fragmentation has no significant impact on other coupling compensation, indicating that farmers' demand for compensation remains constant despite difference in farmland conditions. Even if the farmland is highly fragmented, the farmers will not choose other jobs, because they rely on agriculture for a living. Lacking the knowledge of other jobs, they hope to maintain the current production scale, and safeguard the basic livelihood. 


\section{(6) Production efficiency}

Production efficiency has a positive impact on farmers' selection of financial compensation $(\mathrm{p}<10 \%)$, and a negative impact on that of intellectual technical compensation and alternative fertilizer $(\mathrm{p}<5 \%)$. The higher the production efficiency, the more favorable is financial compensation among the farmers. This agrees well with the provision condition of financial compensation: farmers must know the way to allocate fund to farmland management in an efficient manner. The same explains why farmers do not want technical compensation, especially intellectual compensation like education and training, when the production efficiency is already high.

\section{(7) Farmers' willingness to reduce fertilizer application}

Grain compensation $(\mathrm{p}<1 \%)$ and policy compensation $(\mathrm{p}<10 \%)$ are positively affected by farmers' willingness to reduce fertilizer application, while intellectual technical compensation and alternative fertilizer $(\mathrm{p}<1 \%)$ are negatively affected. In other words, the farmers willing to reduce fertilizer application prefer financial compensation to technical compensation, as such farmers are optimistic about the yield loss. Note that some of these farmers are willing to reduce the amount of fertilizer as a way of conservation tillage. They are willing to bear yield loss as long as it can be eventually compensated. Thus, these farmers have a low demand for intellectual technical compensation and alternative fertilizer.

\section{(8) Regional variable}

Regional variable has a positive impact on financial compensation, grain compensation and policy compensation $(\mathrm{p}<1 \%)$, and a negative impact on intellectual and non-intellectual technical compensations $(\mathrm{p}<1 \%)$. Overall, the farmers living near Qiaodun Reservoir are more likely to accept financial and policy compensations and less likely to accept technical compensation than those near Siming Lake Reservoir. This conclusion is consistent with the actual situation. In the periphery of Qiaodun Reservoir, more than $60 \%$ of family income is from agriculture, owing to the dense population, poor traffic and lack of competitive industry. By contrast, those living near Siming Lake Reservoir have plenty of job opportunities in other industries, and farming income only accounts for $10 \%$ of family income.

\section{Discussion}

This paper explores the farmers' selection of compensation means for chemical fertilizer reduction, and divides the reduction methods into six types, namely, financial compensation, grain compensation, technical learning, alternative fertilizer; organic fertilizer, and policy compensation. Through a questionnaire survey, the farmers' acceptance of different compensation options was summed up as: Besides the popularity option of financial compensation, the farmers are willing to accept non-financial compensation means, and the options with features of transfusion and coupling compensations; the stability is the top concern in the selection process, while function and flexibility are also considered; when multiple options are available, financial compensation is the most favorite one among farmers, followed by technical learning and policy compensation; the organic fertilizer has the lowest acceptance. Next, a simultaneous bivariate probit model was established to illustrate the effect of each 
factor on farmers' selection between intellectual and non-intellectual technical compensations, and between alternative and organic fertilizers. Meanwhile, the farmers' intentions on policy compensation were examined by the binary probit model. The following conclusions were drawn through the empirical analysis on the modelling results.

The farmers' selection process is greatly affected by their awareness of the yield loss risk incurred by the reduction of chemical fertilizer. This risk is difficult to control at least in the short term if the farmers abandon long-term fertilization. However, chemical fertilizer is more controllable than pesticide, and the reduction consequences are not hard to predict. Our research reveals that farmers prefer the combination of compensation options that complement each other, and wish the government could provide compensation in a concentrated and practical manner.

The age of house owner is the key determination of the farmers' selection process. Old farmers are more conservative about alternative options, and stick to financial compensation and grain compensation. By contrast, young farmers are willing to improve farmland management and learn new techniques through intellectual technical compensation.

The education level of house owner has a negatively impact on the selection of grain compensation and intellectual technical compensation. Well-educated farmers are interested in non-financial compensation and policy compensation (other jobs).

The farmland area is negatively correlated with the selection of financial compensation. The farmers owning a large piece of farmland tend to choose alternative options and non-intellectual technical compensation.

The farmland fragmentation suppresses farmers' demand for non-agricultural job opportunities. Even if the farmland is highly fragmented, the farmers will not choose other jobs when they rely on agriculture for a living.

The production efficiency and farmers' willingness to reduce fertilizer application have similar effects on farmers' selection process. The farmers with high production efficiency are willing to reduce the use of chemical fertilizer and receive financial compensation instead of technical compensation. The farmers living near Qiaodun Reservoir, where the social and economic environment is relatively inferior, are more likely to accept financial and policy compensations and less likely to accept technical compensation, than those living near Siming Lake Reservoir. Even so, these farmers expect the government to provide intellectual technical compensation to control the risk of yield loss. In a word, the farmers living near Qiaodun Reservoir demand more opportunities for personal development.

\section{Conclusions}

Based on the above discussions, the following measures were designed for the government to encourage farmers' participation in fertilizer reduction and protect the quality of water bodies.

(1) Integrate different compensation options into a scientific and rational plan for farmers.

Considering the complementary effect between different compensation options, the government is advised to combine several compensation options that serve the same purpose and suit the same type of farmers into an integrated compensation plan, in light 
of the local conditions. Such a plan could promote the farmers' awareness of fertilizer pollution and boost their willingness to adopt reduction measures.

(2) Highlight the guidance of financial compensation on farmers' behaviors.

The financial compensation improves the direct income of any type of farmers, and thus enjoys a high acceptance among them. Despite its obvious incentive effect, the financial compensation should not be provided in advance, due to the presence of moral hazard. Instead, this compensation option should be given after the fertilizer reduction, and used to reward the farmers' purchase of techniques.

(3) Improve the acceptance of technical compensation through various channels.

The rejection of technical compensation is mainly attributable to the myth that farming is an empirical, not technical, process, as well as the farmers' poor awareness of environmental protection and blind trust in traditional low-cost, efficient but polluting tillage methods. To solve the problem, the government should provide regular training in the field and through channels like TV, radio and the Internet, remind the farmers of the importance of water conservation and the harm of chemical fertilizer to water bodies, and subsidize the purchase of alternative techniques to fertilizer application.

(4) Create job opportunities for farmers less willing to cut fertilizer application.

For various reasons, farmers may reject any compensation for fertilizer reduction. These farmers often have a special preference for jobs in other industries. Thus, it is suggested that the government implement "agricultural to non-agricultural" plans, giving these farmers new job opportunities. In places with good agricultural conditions, efforts should be made to develop green agriculture (e.g. family farm and ecological farm) and plant crops (e.g. potatoes and corns) requiring little fertilization. In places with poor agricultural conditions, the excess labor forces should be transferred to the downstream through ecological migration or non-agricultural reemployment. The emigration will benefit the ecology of the water bodies.

On the whole, the paper focuses on discussing whether there is a substitution relationship or complementary relationship between farmers' acquisition intentions of same type of compensation tools, and proposes that various means of compensation should have corresponding optimal providing ways (providing separately or in combination). As the acquisition and adoption of a single compensation tool is not the major concern of the study, there is no further research on the hematopoietic compensation type compensation, "other jobs" as career transfer, which can thoroughly eradicate pollution and is conducive to farmers' creating income. Farmers' career transfer involves the transportation and interconnection of agricultural labor in different employment areas. There are still lots of practical problems crying out for solution such as "what kind of local career transfer mode should be established", "how to formulate farmers' career transfer compensation scheme", "how to guarantee the continuity of employment", "how to ensure the stability of farmers' incomes", and so on. Therefore, it is an area worth further research.

Acknowledgements. Support for this research was provided by Water Culture Research Program of Zhejiang University of Water Resources and Electric Power (Grant No. SWH201802), Project of the Zhejiang Soft Science Research plans (Grant No. 2018C35064), Ministry of Education Humanities and Social Sciences Research Youth Foundation (Grant No.14YJC790124), Zhijiang Young Scholar Program of Social Science Planning of Zhejiang Province (Grant No. 13ZJQN056YB), the Major Program of National Social Science Foundation of China (Grant No. 14ZDA070), National Natural Science Foundation of China (Grant No. 71773114). 


\section{REFERENCES}

[1] Ademila, O., Saloko, B. (2018): Hydrogeoelectrical evaluation of groundwater flow pattern in a Basement Complex terrain, Southwest Nigeria. - Environmental and Earth Sciences Research Journal 5(1): 7-14.

[2] Álvarez, X., Valero, E., Santos, R. M. B., Varandas, S. G. P., Fernandes, L. F. S., Pachecoc, F. A. L. (2017): Anthropogenic nutrients and eutrophication in multiple land use watersheds: Best management practices and policies for the protection of water resources. - Land Use Policy 69: 1-11.

[3] Aretino, B., Holland, P., Matysek, A., Peterson, D. C. (2001): Cost Sharing for Biodiversity Conservation: A Conceptual Framework. - Productivity Commission, Melbourne, Victoria, Australia.

[4] Chang, I. S., Yang, Y. X., Wu, J., Shi, M. M. (2013): Ecological compensation in China progress, problems and prospects//Advanced materials research. - Trans Tech Publications 726: 988-991.

[5] Corneil, D., Villeneuve, B., Piffady, J., Chandesris, A., Usseglio-Polatera, P., Souchon, Y. (2018): Introducing nested spatial scales in multi-stress models: towards better assessment of human impacts on river ecosystems. - Hydrobiologia 806(1): 347-361.

[6] Doreen, A., Joseph, S., Wycliff, T., Daniel, N., Goretty, N. (2018): Land use practices in the rural and urban sub catchments of River Rwizi, Western-Uganda; their effect on its ecological characteristics. - Environmental Science 3(2) 45-50.

[7] Fales, M., Dell, R., Herbert, M. E., Sowa, S. P., Asher, J., O’Neil, G., Doran, P. J., Wickerham, B. (2016): Making the leap from science to implementation: strategic agricultural conservation in Michigan's Saginaw Bay watershed. - Journal of Great Lakes Research 42(6): 1372-1385.

[8] Feng, X. J., Wei, C. F., Xie, D., Shao, J. G., Zhang, P. C. (2006): Effects of farm household's management behavior upon nonpoint pollution of agriculture and model analysis. - Chinese Agricultural Science Bulletin 21(12): 354-358.

[9] Ganiron, J. T. U. (2017): Performance of community water supply management towards designing water safety plan. - World News of Natural Sciences 10: 10-25.

[10] Grafton, Q., Biswas, A. K., Tortajada, C. (2017): Water management: signing up to safe water for billions. - Nature 548(7668): 393.

[11] Greene, W. H. (2008): The Econometric Approach to Efficiency Analysis. The Measurement of Productive Efficiency and Productivity Growth. - in: Fried, H. O., Lovell, C. A. K., Schmidt, S. S. (eds.) The Measurement of Productive Efficiency: Techniques and Applications. Oxford University Press, New York, pp. 68-119.

[12] Herrera, D., Ellis, A., Fisher, B., Golden, C. D., Johnson, K., Mulligan, M., Pfaff, A., Treuer, T., Ricketts, T. H. (2017): Upstream watershed condition predicts rural children's health across 35 developing countries. - Nature Communications 8(1): 811.

[13] Huber, A. C., Bhend, S., Mosler, H. J. (2012): Determinants of exclusive consumption of fluoride-free water: a cross-sectional household study in rural Ethiopia. - Journal of Public Health 20(3): 269-278.

[14] Ji, L., Giampietro, M., Pastore, G., Cai, L. W., Luo, H. E. (1999): Trends of technical changes in rice-based farming systems in Southern China: case study of Qianjiang municipality. - Critical Reviews in Plant Sciences 18(3): 283-297.

[15] Jian, Q. P. (2018): Improvement of radial basis function neural network with accelerated particle swarm optimization for corrosion rate prediction of 3C steel in seawater environment. - Annales de Chimie - Science des Matériaux 42(4): 577-587.

[16] Jin, S. Q. (2013): Traceability, response and suggestions of environmental pollution in rural areas: a survey of rural water pollution investigation in Hunan Province. Economic Research Reference (43): 30-34.

[17] Joldeş, N. T., Gyenge, C., Achimaș, G. (2017): The waste and the environment. Academic Journal of Manufacturing Engineering 15(2): 111-114. 
[18] Karabulut, A., Egoh, B. N., Lanzanova, D. (2016): Mapping water provisioning services to support the ecosystem-water-food-energy nexus in the Danube River basin. Ecosystem Services 17: 278-292.

[19] Klemme, R. M. (1985): A stochastic dominance comparison of reduced tillage systems in corn and soybean production under risk. - American Journal of Agricultural Economics 67(3): 550-556.

[20] Kreuger, J. (1998): Pesticides in stream water within an agricultural catchment in southern Sweden, 1990-1996. - Science of the Total Environment 216(3): 227-251.

[21] Kronvang, B., Andersen, H. E., Børgesen, C., Dalgaard, T., Larsen, S. E., Bøgestrand, J., Blicher-Mathiasen, G. (2008): Effects of policy measures implemented in Denmark on nitrogen pollution of the aquatic environment. - Environmental Science and Policy 11(2): 144-152.

[22] Li, E., Endter-Wada, J., Li, S. (2015): Characterizing and contextualizing the water challenges of megacities. - JAWRA Journal of the American Water Resources Association 51: 589-613.

[23] Li, Z., Deng, X., Wu, F., Hasan, S. S. (2015): Scenario analysis for water resources in response to land use change in the middle and upper reaches of the Heihe River Basin. Sustainability 7(3): 3086-3108.

[24] Liang, Z. F., Xiao, X. C., Ni, J. P. (2015): An empirical analysis of the relation between the farmers' awareness of agricultural nonpoint pollution and their willingness to participate in its control - a case study of Nantuo Town in three Uorges Reservoir area. Journal of Southwest University (Natural Science Edition) 37(3): 125-131.

[25] Macintosh, A., Denniss, R. (2004): Property Rights and the Environment: Should Farmers Have a Right to Compensation. - Australia Institute, Australia.

[26] Moges, M. A., Tilahun, S. A., Ayana, E. K., Moges, M. M., Gabye, N., Giri, S., Steenhuis, T. S. (2016): Non-point source pollution of dissolved phosphorus in the Ethiopian Highlands: the Awramba watershed near Lake Tana. - CLEAN - Soil, Air, Water 44(6): 703-709.

[27] Neumann, K., Verburg, P. H., Elbersen, B., Stehfest, E., Woltjer, G. B. (2011): Multiscale scenarios of spatial-temporal dynamics in the European livestock sector. Agriculture, Ecosystems and Environment 140(1-2): 88-101.

[28] Perry, D. M., Berry, K. A. (2016): Central American integration through infrastructure development: A case study of Costa Rican hydropower. - Regions and Cohesion 6: 96115 .

[29] Pott, C. A., Fohrer, N. (2017): Best management practices to reduce nitrate pollution in a rural watershed in Germany. - Revista Ambiente and Água 12(6): 888-901.

[30] Research Group on China's Ecological Compensation Mechanism and Policy (2007): Research on China's Ecological Compensation Mechanism and Policy. - Science Press, Beijing.

[31] Rodrigues, V., Estrany, J., Ranzini, M., Ciccoc, V., José, M., Martín-Benitod, T., Hedo, J., Lucas-Borjad, M. E. (2018): Effects of land use and seasonality on stream water quality in a small tropical catchment: The headwater of Córrego Água Limpa, São Paulo (Brazil). - Science of the Total Environment 622: 1553-1561.

[32] Shi, C. X., Guo, X. H., Zu, Y. Q., Chen, J. J., Li, Y. (2014): Study on agricultural ecological compensation in the upper reaches of the Bohai Sea basin based on CVM willingness survey. - Journal of Agro-Environment Science 33(4): 730-736.

[33] Smith, L., Inman, A., Lai, X., Zhang, H. F., Meng, F. Q., Zhou, J. B., Burke, S., Rahn, C., Siciliano, G., Haygarth, P. M., Bellarby, J., Surridge, B. (2017): Mitigation of diffuse water pollution from agriculture in England and China and the scope for policy transfer. Land Use Policy 61: 208-219.

[34] Sun, B., Zhang, L., Yang, L. (2012): Agricultural diffused pollution in China: causes and mitigation measures. - Ambio 41(4): 370-379. 
[35] Tian, F., Cao, W. D., Dai, X. L., Ou, M. X. (2018): Flow characteristics of the new type of mixer in wastewater treatment. - International Journal of Heat and Technology 36(3): 913-918.

[36] Villarroya, A., Persson, J., Puig, J. (2014): Ecological compensation: from general guidance and expertise to specific proposals for road developments. - Environmental Impact Assessment Review 45: 54-62.

[37] Vogl, A. L., Goldstein, J. H., Daily, G. C., Vira, B., Bremer, L., McDonald, R. I., Shemie, D., Tellman, B., Cassini, J. (2017): Mainstreaming investments in watershed services to enhance water security: barriers and opportunities. - Environmental Science and Policy 75: 19-27.

[38] Wunder, S. (2015): Revisiting the concept of payments for environmental services. Ecological Economics 117: 234-243.

[39] Xie, L., Li, A. N. (2016): Responsibility distribution or right confirmation: analysis on the applicable conditions of watershed ecological compensation, China population. Resources and Environment 26: 109-115.

[40] Xu, D. W., Liu, C. Y., Chang, L. (2013): Study on the difference of WTP and WTA in ecological acceptance of watershed: based on the CVM survey of residents in the middle reaches of Liaohe River. - Journal of Natural Resources 28(3): 402-409.

[41] Yang, X., Cai, Y. J. (2012): The choice of farmland ecological compensation methods and market operation - an empirical study based on a questionnaire of 383 households in Wuhan. - Resources and Environment in the Yangtza Basin 5: 591-596.

[42] Yihdego, Y., Khalil, A. (2017): Economic and environmental management of water resources: perspective of groundwater. - Global Journal of Human-Social Science Research 17: 44-47.

[43] Ze, H., Wei, S., Deng, X. Z. (2017): Progress in the research on benefit-sharing and ecological compensation mechanisms for transboundary rivers. - Journal of Resources and Ecology 8: 129-140.

[44] Zhang, M. K. (2015): Reflections on the policy and technology for the sustainable prevention and control of non-point-source agricultural pollution in China. - Journal of Zhejiang Agricultural Sciences 56(1): 10-14. 